\title{
Knowledge and frequency of contacts as factors in forming primary school children attitudes towards peers with developmental disabilities
}

\section{Sladjana Djorem ${ }^{1}$, Gordana Odović2, Ana Lukićs Jelena Milićc, Bojan Joksimović ${ }^{4}$, Milena Božinovićc}

'Primary school "Hilmi ef. Šarić", Tarčin, Bosnia and Herzegovina ${ }^{2}$ University of Belgrade, Faculty for special education and rehabilitation, Belgrade, Serbia

${ }^{3}$ Center for specialist social services "For mother and child", Banja Luka, The Republic of Srpska, Bosnia and Herzegovina

${ }^{4}$ University of East Sarajevo, Faculty of Medicine Foca, The Republic of Srpska, Bosnia and Herzegovina

Primljen - Received: 20/04/2021

Prihvaćen - Accepted: 17/06/2021

\section{Corresponding author:}

Sladjana Djorem, BSc in Special Education and Rehabilitation Karadjordjeva 46, 71230 Kalinovik djorem7@gmail.com

Copyright: (2021 Sladjana Djorem et all. This is an Open Access article distributed under the terms of the Creative Commons Attribution 4.0 International (CC BY 4.0) license.

\begin{abstract}
Summary
Introduction. Higher level of knowledge and frequent contacts with peers with disabilities can influence the emergence of more positive attitudes of students towards peers with disabilities. In regard to that, our aim was to test the importance of knowledge, contact frequency and other possible factors influencing attitudes of students toward disabled peers.
\end{abstract}

Methods. The study included 140 students of 4 th and 5 th grade of primary schools. The research was conducted in the period from December 2020 to March 2021 in two primary schools. The Chedoke McMaster scale was used to examine students' attitudes toward peers with disabilities, while Contact with Disabled Persons Scale and the Children's Knowledge about Handicapped Persons Scale were used to assess frequency of contact and knowledge about disabilities.

Results. Girls showed a significantly higher level $(25.21 \pm 6.21)$ of frequency of contacts with students with disabilities compared to boys $(19.66 \pm 7.30)(p=0.043)$ and higher level of knowledge (27.88 \pm 5.88$)$ about disabilities compared to boys $(25.50 \pm 4.69)(p=0.009)$. Respondents who attended school together with children with disabilities (31.07 \pm 8.41$)$ showed a significantly higher level of frequency of contacts with students with disabilities compared to respondents who did not attend school with peers with disabilities (13.72 \pm 6.32$)$ $(\mathrm{p}=0.001)$.

Conclusion. Higher level of knowledge and frequent contacts with peers with disabilities does not have influence on the emergence of more positive attitudes of students towards peers with disabilities.

Key words: attitudes, primary school students, disability

\section{Introduction}

Developmental disabilities are defined as severe, chronic disabilities attributable to mental and/ or physical impairments that are "likely to continue indefinitely", resulting in functional limitations in self-care, learning, receptive or expressive language, self-direction, capacity for economic self-sufficiency and independent living; manifested by the age 22 and requiring care, treatment 
or other services of extended or lifelong duration [1]. World Health Organization estimates that more than a billion people live with some form of disability, or about $15 \%$ of the world's population [2]. The best possible building for an inclusive community is based on education. If children in schools are not taught to work and live in a community, to tolerate and appreciate differences related to origin, religion, culture, nationality, but also differences in cognitive, emotional, social and sensory-motor abilities, it will undoubtedly form a community that puts people with developmental disabilities at a disadvantage [3,4]. Children who have developmental disabilities already have a large number of challenges that have arisen as a result of their difficulties, such as health and social problems, and therefore society should avoid the possible obstacles in front of them in every possible way, including those of an educational nature. In order to avoid these obstacles, in recent years there has been a tendency to provide children with developmental disabilities, with the conditions to reach the maximum in their achievements and to inlude them in the regular educational system $[3,4]$.

Inclusion implies the practice of including children with disabilities in the general education classroom with full involvement of all students in all aspects of schooling [5]. Given that inclusion is a very complex process influenced by many factors, special attention should be paid to the key participants of inclusion (teachers and students) and to their views on this issue, which should be positively directed [5-7]. Unfortunately, the access of children with developmental disabilities to regular schooling does not always guarantee a good outcome, full participation of inclusion members (teachers, pupils and students) or social acceptance. Although several studies have shown positive academic and social benefits of inclusive education $[5,8,9]$, some others show that during inclusion, students with disabilities face a large number of social problems $[10,11]$. For example, students with developmental disabilities are significantly less likely than students without disabilities to report a sense of belonging to society, a sense of acceptance and security, or a feeling that other students are pleasant or kind to them, and significantly more likely to report interpersonal conflicts in school, loneliness and the existence of isolation [10].

It is known from literature that the attitudes of students of typical development towards peers with developmental disabilities range from predominantly negative to moderately positive [3]. It has been recognized that the main barrier to social inclusion in school is the existence of negative attitudes of peers, and these negative attitudes can often manifest themselves in the form of name-calling or harassment of students with developmental disabilities $[12,13]$. The importance of a positive attitude of peers towards children with developmental disabilities is shown by data from the literature, which states that a positive attitude is vital for the progress of students with developmental disabilities. However, in order for students with developmental disabilities to learn and progress to their full potential, it is necessary to find a socially acceptable and supportive environment [14-16].

Since it has already been identified that the emergence of negative attitudes is the beginning of the problem that children with developmental disabilities face during schooling, in order to assess attitudes towards people with disabilities, a large number of studies have been done to improve methods of assessment of attitudes. However, progress in identifying attitudes towards persons with developmental disabilities has been particularly advanced in terms of adult assessment (parents, teachers), but very few studies have worked to assess the knowledge and attitudes of children [3,4,17-19].

Although in our country there is a tendency towards inclusion in education, the literature lacks data on the attitudes of students towards the inclusion of their peers who have 
developmental disabilities. There is a large amount of data in the literature on the attitudes of teachers and parents towards inclusion, but there is not much data on the attitudes, as well as frequency of contact and knowledge of children about their peers with developmental disabilities $[20,21]$. It is very important to understand the attitudes of the participants in inclusion and in which population of children negative attitudes occur more often, because only in this way it is possible to properly formulate and successfully implement inclusive education policy. This is the reason why this topic was chosen, and the main goal of the research was to examine whether there is a difference in attitudes, knowledge and frequency of contact with peers with developmental disabilities, between groups of respondents divided by gender, age and inclusion. Also, the objective of the research was to determine correlation between attitudes, frequency of contact and knowledge of students of typical development towards peers with developmental disabilities.

\section{Methods}

Prior to conducting the research, consents were collected from parents whose children participated in the research. A survey was conducted after all obtained consents. The study included 140 respondents, divided into two groups. The first group was consisted of 70 respondents from the typical population which attended classes together with children with developmental disabilities (group with inclusion). The other group was consisted of children from the typical population, which did not attend classes together with children with disabilities (group without inclusion). Students with disabilities attended classes according to a customized program from the first grade with their peers, and had a diagnosis of learning difficulties, as well as moderate intellectual disabilities. The study included approximately equal numbers of male and female respondents. Out of the total num- ber of respondents, 71 (50.7\%) were boys, while the remaining $69(49.3 \%)$ were girls. Out of the total number of surveyed children, $30(21.4 \%)$ were nine years old, the majority, $66(47.1 \%)$ were ten years old, while 44 (31.4\%) were eleven years old. Half of the respondents were the fourth grade students of primary school $(50 \%)$, while the remaining $70(50 \%)$ attended the fifth grade of primary school (Table 1 ).

Table 1. Respondent's socio-demographic characteristics

\begin{tabular}{lc} 
Characteristics & $\begin{array}{c}\text { Number }(\%), \text { or } \\
\text { Mean } \pm \text { SD }\end{array}$ \\
\hline $\begin{array}{l}\text { Gender } \\
\text { Boys } \\
\text { Girls }\end{array}$ & $71(50.7)$ \\
Age & $69(49.3)$ \\
$\quad$ Mean age, Y (SD) & \\
9 years & $23.1 \pm 2.8$ \\
10 years & $30(21.4)$ \\
11 years & $66(47.1)$ \\
Grade & $44(31.4)$ \\
Fourth grade & \\
Fifth grade & $70(50.0)$ \\
\end{tabular}

The research was conducted in two primary schools, "Hilmi ef. Saric" in Tarčin and in the primary school "9. maj" in Pazarić. Demographic data, gender, age, grade were collected through a specially compiled questionnaire, while achievement of students was collected from the grade book in collaboration with the class teachers involved in the research. The research was conducted in the period from December 2020 to March 2021.

Three scales were used in our research Chedoke-McMaster Attitudes Towards Children with Handicaps scale (CATCH) [22], Contact with Disabled Persons Scale (CDP) [23] and the Children's Knowledge about Handicapped Persons Scale (CKHPS) [24]. All three instruments have been translated into Serbian for the purposes of previous research, and we used that version of the instrument [25].

Attitudes of primary school students towards children with disabilities were assessed 
by the CATCH scale. Since the research was aimed at assessing attitudes towards students with disabilities, the term "handicap" has been replaced by the term "developmental disabilities." This scale has been translated into Serbian by Talijan et al. [25] and that version was used. The CATCH scale is based on the three-component model of attitudes and encompasses the cognitive, affective, and behavioral domains. The scale includes 36 items with an equal number of positive and negative statements. The total score of the respondents was obtained by summing the items, dividing the sum by the number of particles and then multiplying by 10, while the score of separate domains was calculated by adding the number of points and then divided by the number of questions [26]. The higher score on the scale indicates more positive attitudes. Factor analysis of Rosenbaum et al. [22] showed that factors one and three included affective and behavioral items, and factor two cognitive items, the three-component model of attitudes was not confirmed, and authors suggested that a two-component model may be more appropriate. Therefore, in our research we used a two-component model of attitudes. The reliability of internal consistency for the scale as a whole is high $(\alpha=0.909)$, as well as for the affective-behavioral component $(\alpha=0.901)$, while this value is acceptable for the cognitive component ( $\alpha=0.705)$ [27].

In an original CDP scale the items are adapted to the experience of primary school children so that the scale will be focused on assessing the frequency of contact with children with disabilities. This scale consists of twenty items and the frequency of contact may be from never to very often. In order to assess psychometric characteristics, the authors of the scale conducted a study on a sample of 238 people. The internal consistency measured by the Cronbach alpha coefficient was 0.92 [23].

Knowledge of Persons with Disabilities was assessed using the CKHPS scale. The instrument includes 25 items that can be answered on a three-point scale: 0 (no), 1 (not sure) and 2 (yes). Scores can range from zero to 50 , and a higher score indicates more knowledge about developmental disabilities. In order to assess the psychometric properties of the scale, Hazard (24) conducted a study on a sample of 411 students attending primary school. The results of the study showed that the reliability, estimated by the Spearman-Brown coefficient, is 0.53 [24].

The methods of descriptive and analytical statistics were used in the paper. Among the methods of descriptive statistics, measures of central tendency and measures of variability were used, namely: arithmetic mean with standard deviation and relative numbers for categorical variables. Distribution was normal and among the methods of analytical statistics Student's t-test and numerical one-factor analysis of variance (ANOVA) for bound samples were used to determine differences in mean values between two or more groups of respondents. Of the nonparametric tests, the chi-square test was used to assess the difference between the groups. For the correlation analysis, Pearson's correlation coefficient was used. The usual value of $p<0.05$ was taken as the level of statistical significance of differences. Results were statistically analyzed in GraphPad Prism software (GraphPad, La Jolla, CA, USA) and SPSS software package version 21.0 (Statistical Package for Social Sciences SPSS 21.0 Inc, USA).

\section{Results}

There was no statistically significant difference between the groups of respondents divided in relation to gender in the average values of the total score of attitudes, affective-behavioral domain or cognitive domain of attitudes towards students with disabilities. A statistically significant difference ( $\mathrm{t}=-2.315 ; \mathrm{p}=0.043$ ) was observed between boys and girls in the average values of 
the CDP scale which estimates the frequency of contacts with students with developmental disabilities. Girls $(25.21 \pm 6.21)$ showed a significantly higher level of contact frequency with children with disabilities compared to boys (19.66 \pm 7.30$)$. A statistically significant difference $(t=-2.647 ; p=0.009)$ was observed between boys and girls in the average values of the CKHPS scale of children's knowledge about persons with disabilities. Girls (27.88 \pm 5.88$)$ showed a higher level of knowledge about people or children with disabilities compared to boys

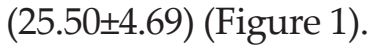

There was no statistically significant difference between the groups of children divided by age at 9, 10 and 11 years in the average values of attitudes towards children with disabilities, as well as the affective-behavioral or cognitive domain of attitudes, and no difference was observed in the frequency of contacts, nor knowledge about people with disabilities (Table 2).
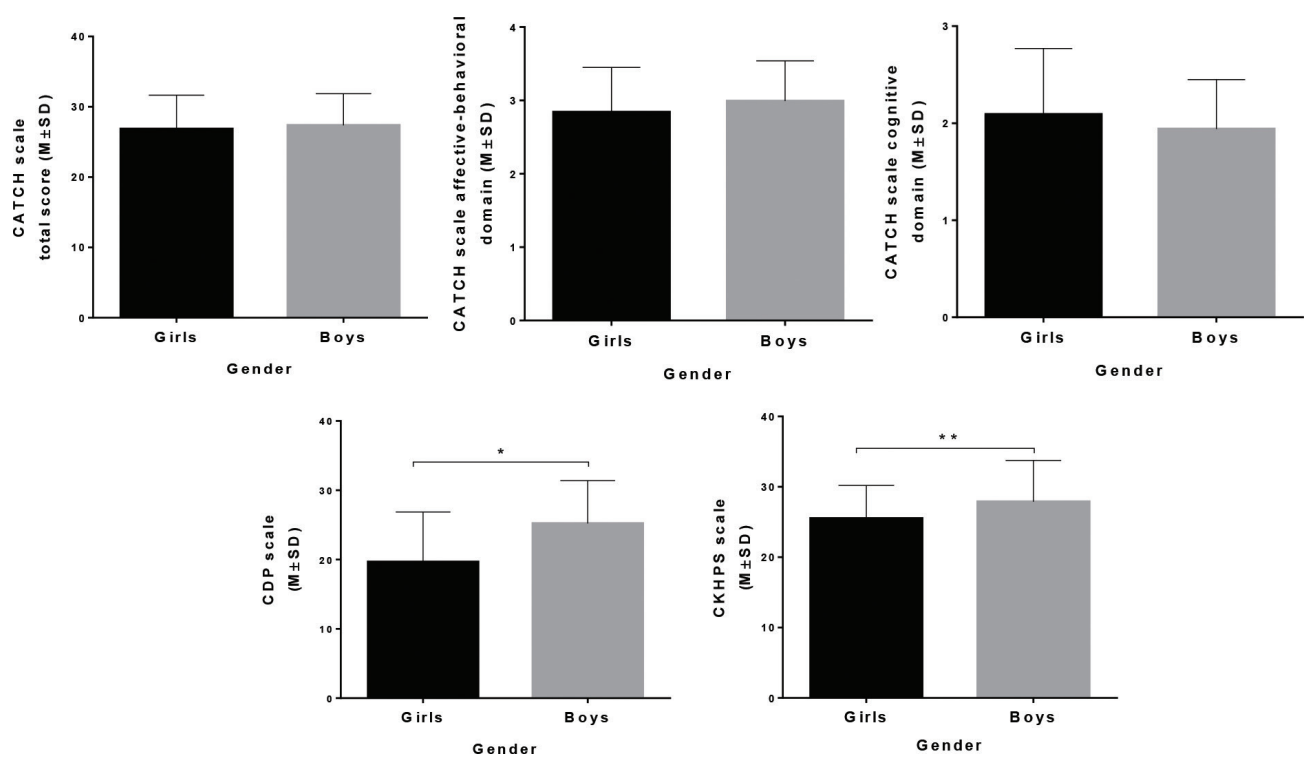

Figure 1. Mean values of attitudes, frequency of contact and knowledge between respondents divided by gender. CATCH - Chedoke-McMaster Attitudes Towards Children with Handicaps scale; CDP - The Contact with Disabled Persons Scale; CKHPS - Children's Knowledge about Handicapped Persons Scale, M-mean, SD-standard deviation; * $p<0.05 ;{ }^{* *} p<0.001$.

Table 2. Attitudes, frequency of contacts and knowledge about people with disabilities in relation to the age of the respondents

\begin{tabular}{cccccc}
\hline $\begin{array}{c}\text { Attitudes, frequency of contact and } \\
\text { knowledge about developmental } \\
\text { disabilities }\end{array}$ & \multicolumn{3}{c}{$\begin{array}{c}\text { Age } \\
\text { Number (\%) }\end{array}$} & F & $\mathbf{p}$ \\
\cline { 2 - 5 } & $\mathbf{9}$ years & $\mathbf{1 0}$ years & $\mathbf{1 1}$ years & & \\
\hline CATCH (totale score) & $26.18 \pm 4.89$ & $27.35 \pm 4.35$ & $27.32 \pm 4.99$ & 0.719 & 0.489 \\
Affective-behavioral domain & $2.71 \pm 0.53$ & $2.95 \pm 0.54$ & $3.01 \pm 0.69$ & 2.501 & 0.086 \\
Cognitive domain & $2.22 \pm 0.43$ & $1.98 \pm 0.70$ & $1.94 \pm 0.54$ & 2.272 & 0.107 \\
CDP (total score) & $21.50 \pm 7.31$ & $22.45 \pm 7.51$ & $22.93 \pm 9.98$ & 0.055 & 0.947 \\
CKHPS (total score) & $25.20 \pm 6.20$ & $27.39 \pm 5.50$ & $26.61 \pm 4.60$ & 1.708 & 0.185 \\
\hline
\end{tabular}


Neither statistically significant difference in the average values of the total score of attitudes towards students with disabilities, affective-behavioral or cognitive domain, nor knowledge about people or children with disabilities was observed between the groups of respondents divided in relation to inclusion. Between the groups of respondents divided into groups in relation to whether they attend classes together with students with disabilities or not, a statistically significant difference $(t=6.386 ; p=0.001)$ was observed in the average values of the scale for assessing the frequency of contacts with children with developmental disabilities. Respondents who attend school together with children with disabilities (31.07 \pm 8.41$)$ showed a significantly higher level of frequency in contacts with students with disabilities compared to respondents who do not attend school with peers with disabilities $(13,72 \pm 6.32)$ (Figure 2).
Pearson's correlation coefficient showed the existence of a statistically significant positive and strong correlation between the overall score of attitudes towards children with disabilities with the affective-behavioral domain of attitudes $(r=0.939 ; p<0.01)$, as well as moderately strong and positive correlations with cognitive attitude domain $(\mathrm{r}=0.432 ; \mathrm{p}<0.01)$. A statistically significant, weak and positive correlation was also observed between the affective-behavioral and cognitive domains of attitudes $(r=0.172 ; p<0.05)$. These results show that children who have more positive attitude towards children with disabilities, at the same time have higher level of affective-behavioral and cognitive attitudes. A statistically significant correlation between the frequency of contact and knowledge about persons with disabilities in relation to the attitude of the respondents towards students with disabilities was not observed (Table 3).
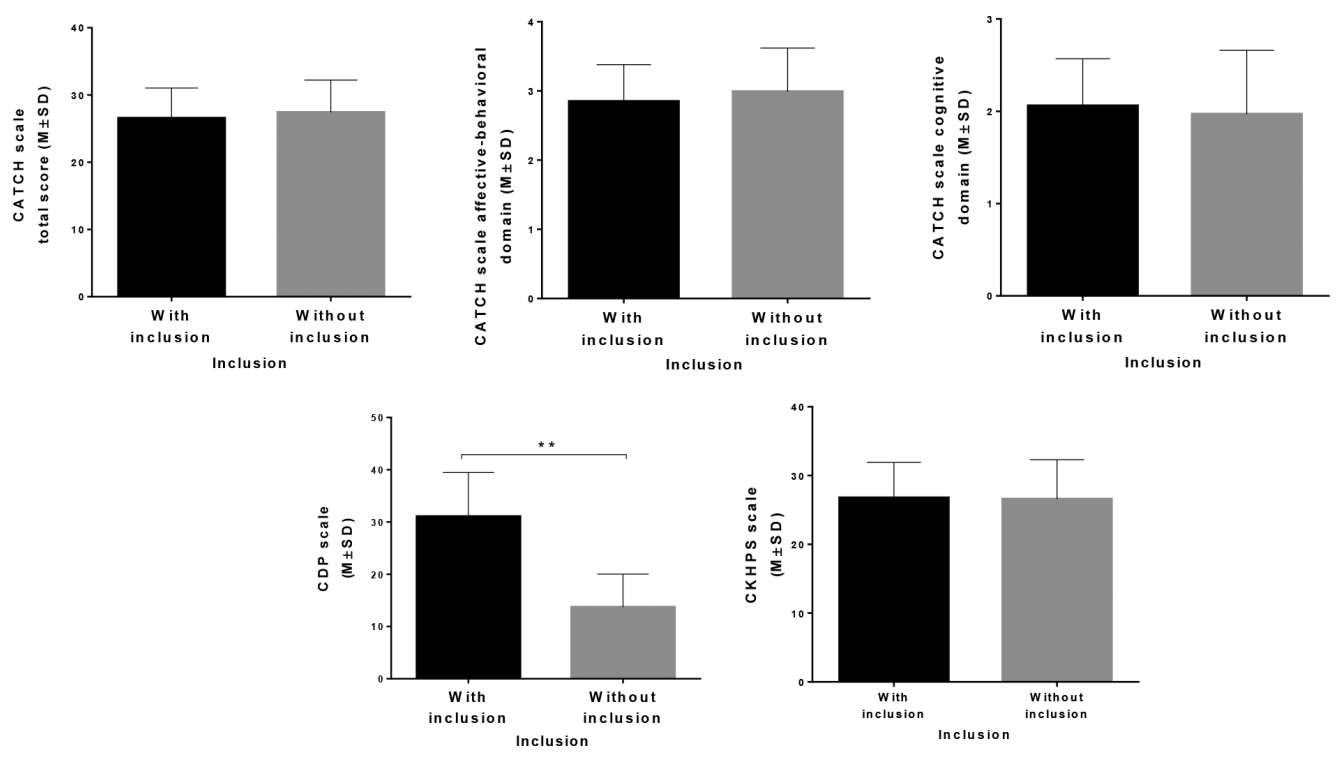

Figure 2. Mean values of attitudes, frequency of contact and knowledge between respondents divided by inclusion. CATCH - Chedoke-McMaster Attitudes Towards Children with Handicaps scale; CDP - The Contact with Disabled Persons Scale; CKHPS - Children's Knowledge about Handicapped Persons Scale, $M$ - mean, SD-standard deviation; * $p<0.05$; ${ }^{* *} p<0.001$. 
Table 3. Correlation between the frequency of contact and knowledge about people with disabilities in relation to the attitude of respondents towards children with disabilities

\begin{tabular}{|c|c|c|c|c|c|}
\hline & $\begin{array}{l}\text { Attitudes } \\
\text { (total score) }\end{array}$ & $\begin{array}{l}\text { Affective- } \\
\text {-behavioral } \\
\text { domain } \\
\text { (attitudes) }\end{array}$ & $\begin{array}{l}\text { Cognitive do- } \\
\text { main } \\
\text { (attitudes) }\end{array}$ & $\begin{array}{l}\text { Frequency of } \\
\text { contact }\end{array}$ & $\begin{array}{c}\text { Knowledge } \\
\text { about } \\
\text { people with } \\
\text { disabilities }\end{array}$ \\
\hline \multicolumn{6}{|l|}{$\begin{array}{l}\text { Attitudes } \\
\text { (total score) }\end{array}$} \\
\hline $\begin{array}{c}\text { Affective-behavioral } \\
\text { domain (attitudes) }\end{array}$ & $0.939 * *$ & & & & \\
\hline $\begin{array}{l}\text { Cognitive domain } \\
\text { (attitudes) }\end{array}$ & $0.432^{* *}$ & $0.172^{*}$ & & & \\
\hline Frequency of contact & 0.100 & 0.133 & 0.055 & & \\
\hline $\begin{array}{c}\text { Knowledge about } \\
\text { people with } \\
\text { disabilities }\end{array}$ & 0.063 & 0.073 & -0.148 & 0.020 & \\
\hline
\end{tabular}

Pearson's correlation coefficient $(r)$ was used, $r$ values are shown in the table. ${ }^{*} p<0,05,{ }^{* *} p<0,01$

\section{Discussion}

In our study, we examined 140 fourth and fifth grade students. In relation to inclusion, we divided the respondents into two groups, a group of 70 respondents who do not attend classes together with students with disabilities and a group of 70 respondents who attend classes together with their peers with disabilities. In our research, neither statistically significant difference was observed between students who are in inclusion and those who are not in the overall score of attitudes, nor in the affective-behavioral or cognitive domain of attitudes. Our results are confirmed by the research of Dyson et al. [5] conducted on a sample of 77 children in Canada, which found that the attitudes of children with typical development, who had contact with children with developmental disabilities, were almost the same as those of children with typical development who had no contact with children with developmental disabilities [5]. Although most studies have shown conflicting results compared to ours and Dyson et al. [5], that children attending school with children with developmental disabilities have a significantly higher level of positive attitudes compared to children who do not attend inclusive classes and have never been in contact with a peer who has developmental disabilities $[8,28]$. A study conducted in Canada [28] on a sample of nearly 2,000 students showed a statistically significantly higher average value of the overall score of attitudes toward children with disabilities in children who are included, compared to children who are not. Also, the study of Nikolaraizi et al. [8] conducted in the United States of America (USA) and Greece has shown that children who are included accept children with developmental disabilities significantly faster and better than children who are not included [8].Although these results are encouraging, all mentioned studies indicate that children in inclusion have a positive attitude towards children with developmental disabilities, but they are not interested in socializing, playing, sitting together on a school bench or learning with peers with disabilities $[8,28]$. These results show that the existence of 
a positive attitude of students does not mean their willingness to fully accept children with disabilities.

Most of the studies show that girls have a significantly more positive attitude towards peers who have developmental disabilities, which could be explained by the earlier development of empathy in relation to boys $[18,19]$. In our study, we neither observed a statistically significant difference between girls and boys in attitudes, nor between different groups of respondents divided by age. However, there are studies whose results collaborate with our results [29], where no differences in attitudes were observed between boys and girls.

Contact is defined as personal experience with members of a stigmatized group, and the effect of contacts on forming attitudes is the focus of a large number of studies that have shown that general personal contact with a person with a developmental disability has a positive effect on reducing negative attitudes. However, the relationship between contact and attitudes is much more complex, because making contact with a person with a developmental disability does not always result in the formation of positive attitudes $[19,30]$. Our results showed that there was no significant correlation between frequency of contact and attitudes of the respondents towards peers with developmental disabilities. Our results were confirmed in a study by Barr and Brachitta [31] who showed that a mere contact with people with disabilities was not necessarily correlated with positive attitudes and that better predictor of positive attitudes was the type of disability one had contact with [31]. However, our results showed that girls $(25.21 \pm 6.21)$ had a significantly higher $(p=0.043)$ level of contact frequency with students with developmental disabilities compared to boys (19.66 \pm 7.30 ). In our study we showed that contact with children with developmental disabilities was significantly $(p=0.001)$ more frequent from re- spondents who attend school together with children with disabilities in comparison to respondents who do not attend school with peers with disabilities. However, between groups of children divided by age, we did not observe a significant difference in the average values of total score of CDP scale. These results showed that girls and included children were more willing to communicate and socialize with peers who have developmental disabilities compared to boys.

Acceptance of peers with developmental disabilities usually increases with age, most often because children gain more knowledge about the world around them as they grow. On the other hand, this knowledge does not always have to be positive, so it happens that children also learn negative cultural values and norms related to disabilities. According to a study by Hazzard et al. [24], conducted in the USA, on a sample of 367 students in which knowledge about people with disabilities was examined, no statistically significant difference was observed between boys and girls. However, the authors observed that older students (10 and 11 years of age) had significantly higher level of knowledge about people with disabilities compared to younger students (8 and 9 years). In contrast to this study, we did not notice a significant difference in the average values of the total score of CKHPS scale, neither in the score of CATCH and CDP scores between the groups of children aged 9, 10 and 11 . However, the results of our study showed that girls $(27.88 \pm 5.88)$ had a significantly higher level of knowledge about disabilities compared to boys $(25.50 \pm 4.69)(\mathrm{p}=0.009)$. The importance of acquiring knowledge about people with disabilities is shown in a study by Talijan et al. [25] in which a change in attitudes toward students with Down syndrome was examined using an imaginary contact program. The experimental group was educated by a program of imagining contact with children with Down syndrome for 6 weeks, while the control group 
of the examined children was not educated in that period. The authors found that in the experimental group of children after education, the total score of attitudes $(109.72 \pm 20.79)$ and knowledge (34.36 \pm 8.90$)$ about persons with developmental disabilities was statistically significantly higher than the score of attitudes $(73,52 \pm 23.57)(\mathrm{p}<0.001)$ and knowledge $(31.12 \pm 6.23) \quad(p=0.031)$ before education by imaginary contact, while in the control group of examined students no statistically significant difference was observed, before and after the period without education.

One of the goals of the study by Hazzard et al. [24] was to examine whether knowledge had an impact on the attitudes of peers who have a disability. The study found that there was a statistically significant and positive correlation between knowledge and attitudes $(r=0.350 ; p<0.001)$, which means that children who have more knowledge about people with disabilities have a more positive attitude and they accept these children better. Based on this data we assumed that children who have more knowledge about children with developmental disabilities also have more positive attitudes. However, our study did not find a

Funding source. The authors received no specific funding for this work.

Ethical approval. The Ethics Committee of the Primary school "Hilmi ef. Šarić", Tarčin, approved the study and informed consent was obtained from all the individual re- statistically significant correlation between the knowledge or frequency of contacts in relation to the attitudes of respondents towards students with disabilities, which means that we found that higher frequency of contact and higher level of knowledge do not mean more positive attitude.

\section{Conclusion}

Our research has shown that girls have a significantly higher level of knowledge and frequency of contacts toward peers with developmental disabilities. Also, students who are included have more frequent contacts with peers with developmental disabilities than students who are not included, but difference in terms of attitudes and knowledge were not observed. The differences in attitudes, frequency of contact and knowledge between groups divided by age were not observed. Our findings suggest that frequency of contacts and knowledge of students about peers with disabilities does not impact the formation of more positive attitudes towards students with developmental disabilities.

spondents. The research was conducted according to the Declaration of Helsinki.

Conflicts of interest. The authors declare no conflict of interest. 
References:

1. Larson SA, Lakin KC, Anderson L, Kwak Lee N, Lee JH, Anderson D. Prevalence of mental retardation and developmental disabilities: estimates from the 1994/1995 National Health Interview Survey Disability Supplements. Am J Ment Retard 2001;106(3):231-52.

2. Organization WH. WORLD REPORT ON DISABILITY 2011: WHO; 2011 [cited 2021 04.06.2021]. Available from: https://www.who. int/disabilities/world_report/2011/report.pdf.

3. Bermanec J. Inkluzija učenika s teškoćama u razvoju u srednje škole - stavovi učenika i nastavnika [Diplomski rad]. Osijek: Sveučilište Josipa Jurja Strossmayera u Osijeku, Medicinski fakultet Osijek; 2018 [pristupljeno 15.04.2021.] Dostupno na: https://urn.nsk.hr/urn:nbn:hr:152:970636.

4. Đević RS. Socijalna interakcija učenika sa smetnjama u razvoju u osnovnoj školi. Univerzitet u Beogradu. 2015. Available from: http://nardus. mpn.gov.rs/handle/123456789/4550

5. Dyson LL. Kindergarten children's understanding of and attitudes toward people with disabilities. Topics in Early Childhood Special Education 2005;25(2):95-105.

6. Woodgate RL, Gonzalez M, Demczuk L, Snow WM, Barriage S, Kirk S. How do peers promote social inclusion of children with disabilities? A mixed-methods systematic review. Disabil Rehabil 2020;42(18):2553-79.

7. Afkar R, Yarrow N, Surbakti S, Cooper R. Inclusion in Indonesia's Education Sector: A Subnational Review of Gender Gaps and Children with Disabilities: The World Bank; 2020.

8. Nikolaraizi M, Kumar P, Favazza P, Sideridis G, Koulousiou D, Riall A. A cross-cultural examination of typically developing children's attitudes toward individuals with special needs. International Journal of Disability, Development and Education 2005;52(2):101-19.

9. Mrug S, Wallander JL. Self-Concept of Young People with Physical Disabilities: does integration play a role? International Journal of Disability, Development and Education 2002;49(3):267-80.

10. Hogan A, McLellan L, Bauman A. Health promotion needs of young people with disabil- ities - - a population study. Disabil Rehabil 2000;22(8):352-7.

11. Llewellyn A. Perceptions of mainstreaming: A systems approach. Dev Med Child Neurol 2000;42(2):106-15.

12. Nowicki EA, Sandieson R. A meta-analysis of school-age children's attitudes towards persons with physical or intellectual disabilities. International Journal of Disability, Development and Education 2002;49(3):243-65.

13. Wells M, Mitchell KJ, Jones LM, Turner HA. Peer harassment among youths with different disabilities: Impact of harassment online, in person, and in mixed online and in-person incidents. Children \& Schools 2019;41(1):17-24.

14. J. Simeonsson DC, Gail S. Huntington, Janey Sturtz McMillen, J. Lytle Brent, Rune. Students with disabilities: A national survey of participation in school activities. Disabil Rehabil 2001;23(2):49-63.

15. Steinhardt F, Ullenhag A, Jahnsen R, Dolva A-S. Perceived facilitators and barriers for participation in leisure activities in children with disabilities: perspectives of children, parents and professionals. Scandinavian journal of occupational therapy 2021;28(2):121-35.

16. Kart A, Kart M. Academic and Social Effects of Inclusion on Students without Disabilities: A Review of the Literature. Educ Sci 2021;11(1):16.

17. Yu S, Ostrosky MM, Fowler SA. Measuring young children's attitudes toward peers with disabilities: Highlights from the research. Topics in Early Childhood Special Education 2012;32(3):132-42.

18. King SM, Rosenbaum P, Armstrong RW, Milner R. An epidemiological study of children's attitudes toward disability. Dev Med Child Neurol 1989;31(2):237-45.

19. Vignes C, Godeau E, Sentenac M, Coley N, Navarro F, Grandjean $\mathrm{H}$, et al. Determinants of students' attitudes towards peers with disabilities. Dev Med Child Neurol 2009;51(6):473-9.

20. Boyle C, Anderson J, Allen K-A. The importance of teacher attitudes to inclusive education. Inclusive education: Global issues and controversies: Brill Sense; 2020. p. 127-46. 
21. Paseka A, Schwab S. Parents' attitudes towards inclusive education and their perceptions of inclusive teaching practices and resources. Eur J Spec Needs Educ 2020;35(2):254-72.

22. Rosenbaum PL, Armstrong RW, King SM. Children's attitudes toward disabled peers: A self-report measure. J Pediatr Psychol 1986;11(4):517-30.

23. Yuker HE, Hurley MK. Contact with and attitudes toward persons with disabilities: The measurement of intergroup contact. Rehabil Psychol 1987;32(3):145-54.

24. Hazzard A. Children's experience with, knowledge of, and attitude toward disabled persons. J Spec Educ 1983;17(2):131-9.

25. Talijan B. K. Promena stavova prema učenicima sa Daunovim sindromom primenom programa zamišljenog kontakta. Specijalna edukacija i rehabilitacija 2017;16(2):173-95.

26. Plantak P. Stavovi osnovnoškolske djece prema osobama s invaliditetom [Diplomski rad]. Rijeka: Sveučilište u Rijeci, Filozofski fakultet; 2017 [pristupljeno 20.02.2021.] Dostupno na: https://urn.nsk.hr/urn:nbn:hr:186:622333.
27. Talijan B. K, Brojčin B, Glumbić N. Stavovi učenika prema vršnjacima sa Daunovim sindromom. Beogradska defektološka škola - Belgrade School of Special Education and Rehabilitation 2018;24(1):9-28.

28. McDougall* J, DeWit DJ, King G, Miller LT, Killip S. High School-Aged Youths' Attitudes Toward their Peers with Disabilities: the role of school and student interpersonal Factors. International Journal of Disability, Development and Education 2004;51(3):287-313.

29. Spreng* RN, McKinnon* MC, Mar RA, Levine B. The Toronto Empathy Questionnaire: Scale development and initial validation of a factor-analytic solution to multiple empathy measures. J Pers Assess 2009;91(1):62-71.

30. Pettigrew TF, Tropp LR. A meta-analytic test of intergroup contact theory. J Pers Soc Psychol 2006;90(5):751-83.

31. Barr JJ, Bracchitta K. Attitudes toward individuals with disabilities: The effects of contact with different disability types. Curr Psychol 2015;34(2): 223-38. 


\title{
Znanje i učestalost kontakata kao faktora u formiranju stavova djece osnovnoškolskog uzrasta prema vršnjacima sa smetnjama u razvoju
}

\author{
Slađana Đorem ', Gordana Odović , Ana Lukić3, \\ Jelena Milić, Bojan Joksimović ${ }^{4}$, Milena Božinović ${ }^{4}$ \\ 'Osnovna škola „Hilmi ef. Šarić", Tarčin, Bosna i Hercegovina \\ 'Univerzitet u Beogradu, Fakultet za specijalnu edukaciju i rehabilitaciju, Beograd, Srbija \\ "USZ Centar za specijalističke socijalne usluge „Za majku i dijete“, Banja Luka, Republika Srpska, Bo- \\ sna i Hercegovina \\ ${ }^{4}$ Univerzitet u Istočnom Sarajevu, Medicinski fakultet Foča, Republika Srpska, Bosna i Hercegovina
}

Uvod. Viši nivo znanja i česti kontakti sa vršnjacima sa smetnjama u razvoju mogu uticati na pojavu pozitivnijih stavova učenika prema vršnjacima sa smetnjama u razvoju. Cilj istraživanja je bio da se ispita važnost znanja, učestalosti kontakata i drugih faktora koji mogu uticati na stavove učenika tipične populacije prema vršnjacima sa smetnjama u razvoju.

Metode. Studija je obuhvatila 140 učenika 4. i 5. razreda osnovnih škola. Istraživanje je sprovedeno u periodu od decembra 2020. do marta 2021. godine, u dvije osnovne škole. Chedok McMaster skala korišćena je za ispitivanje stavova učenika prema vršnjacima sa smetnjom u razvoju, dok su skala za kontakt sa hendikepiranim osobama i skala o znanju djece o osobama sa smetnjama u razvoju korišćene za procjenu učestalosti kontakata i znanja o smetnjama u razvoju.

Rezultati. Djevojčice su pokazale značajno viši nivo $(25,21 \pm 6,21)$ učestalosti u kontaktima sa učenicima sa smetnjom u razvoju u poređenju sa dječacima $(19,66 \pm 7,30)(p=0,043)$ i viši nivo znanja $(27,88$ $\pm 5,88)$ o smetnjama u razvoju u poređenju sa dječacima $(25,50 \pm 4,69)(p=0,009)$. Ispitanici koji školu pohađaju zajedno sa djecom sa smetnjama u razvoju $(31,07 \pm 8,41)$ pokazali su znatno veći nivo učestalosti kontakata sa učenicima sa smetnjama u razvoju u odnosu na ispitanike koji ne pohađaju školu sa vršnjacima sa smetnjama u razvoju $(13,72 \pm 6,32)(p=0,001)$.

Zaključak. Naše istraživanje je pokazalo da djevojčice imaju viši nivo znanja i kontakata prema vršnjacima sa smetnjama u razvoju. Takođe, učenici koji su u inkluziji imaju češće kontakte sa vršnjacima sa smetnjama u razvoju od učenika koji nisu u inkluziji.

Ključne riječi: stavovi, učenici osnovne škole, smetnje u razvoju 